\title{
INDUSTRIAL CULTURE AS AN EMERGING TOPIC IN REGIONAL DEVELOPMENT?
}

DOI: http://dx.doi.org/10.18509/GBP.2017.20

UDC: 911.374 .4

\author{
Jörn Harfst \\ Danko Simić \\ University of Graz, Department of Geography and Regional Science, Austria
}

\begin{abstract}
Against a new round of socio-economic change, (i.e. 'Industry4.0', 'Knowledge Economy') many small and medium-sized industrial towns outside agglomeration areas, have renewed problems in attracting economic development in the same way as larger cities. This article refers to the term Industrial Culture, as a tool to unlock previously unused potentials in such areas. It show along some examples to potential of Industrial Culture to mobilise new endogenous potentials in (old) industrialised regions, tackling place-bound problems or needs of the municipalities or sectors - thereby focussing directly on (perceived) needs of regional development in the regions. While aims and outcomes of the activities discussed in this article are rather long-term and thus difficult to assess, these approaches allow regions to tap in already existing resources, in addressing important part of the history and presence of (old) industrial places. Thereby it reaches a higher level of acceptance and regional stakeholders can be motivated to sustain this development, creating an interesting platform for regional dialogue and action.
\end{abstract}

Keywords: Industrial Culture, Regional Development, EU policies, Territorial Potentials, Small- and medium-sized towns

\section{INTRODUCTION}

In the frame of major societal and economic changes, Europe's industrial societies transformed over the last decades towards interlinked information societies which are increasingly based on knowledge-intensive services and creative industries. However, these developments are affecting territories in very different and uneven ways. Urban agglomerations are the major hubs in these developments, being the preferred location of innovation and the knowledge economy, often merging manufacturing and design sectors. By contrast, small and medium-sized towns in rural environments often continue to have a small industrial base. Moreover these regions do not succeed in attracting knowledge economy in the same way as large cities.

At the same time, political attention to industrial production is increasing in the aftermath of the financial crisis. In a recent communication to the EU Parliament, the EU Commission 'considers that a strong industrial base will be of key importance for Europe's economic recovery and competitiveness' [1]. In a similar vein, national and regional governments set up strategies for reindustrialisation through the development of 'Industry 4.0' or smart specialisation strategies - both aiming at an increased valorisation of industrial labour. Additionally, one can notice a new interest in former industrial sites 
and heritage locations by utilising them as sites for events or exhibition centres, often connected to events, such as the Cultural Capital of Europe award (e.g. Ruhr 2012), or World Heritage titles (e.g. Völklinger Hütte). To understand these trends and their possible impact on regional development in peripheral, old-industrialised areas in Central Europe, this article will refer to the term Industrial Culture, as a tool to unlock un-used potentials in such areas.

This article will discuss the situation by referring to the recently started 'InduCult2.0' Central Europe INTERREG project (2016-2019) focussing on Industrial Culture in smalland medium-sized towns (www.inducult.eu). By drawing on the project aims, this article will briefly introduce framework conditions of Industrial Culture and the specific challenges in former industrialised towns outside agglomeration areas (section 2). To illustrate the use of Industrial Culture the paper will give three examples from across Central Europe (section 3) and finally discuss the main points in a conclusion (final section).

\section{INDUSTRIAL CULTURE - A THEORETICAL BACKGROUND}

Industrial Culture is a term that has no coherent definition, especially when taking into account different national contexts. It is often narrowed down to the physical remains of former industrial sites and their preservation or re-utilisation, often as sites for cultural events, education or other purposes. This understanding of Industrial Culture is captured best in the German expression 'Industriekultur', which focuses mostly on the tangible remains of industry, i.e. buildings, infrastructures and landscapes [2]. While this approach is indeed an important and the most wide-spread utilisation of the industrial past, previous research has highlighted already broader utilisations including also intangible aspects of the industrial past, focussing on skills, traditions and mind-sets [3], thereby addressing more the Anglo-American understanding of 'Industrial Culture', as a comprehensive 'milieu' of social and physical remains [4].

Industrial Culture in its broader sense has gained an unprecedented popularity across various sectors in the recent decades. Not only several world heritage titles and initiatives address the industrial past (e.g. UNESCO heritage application 'Ore mountains', European Route for Industrial Heritage), but also spectacular events like Cultural Capital in the Ruhr 2012, have celebrated the (bygone) era of intensive, industrial mass production. In this context, cultural heritage has been identified in numerous EU strategies as an important driver of change [5], mainly in relation to the tourism sector, but also in context of creating a joint European identity [6]. Various scientific articles proof this relation, having led to a trend where towns and cities 'rediscover' their industrial heritage, despite the often subdued value of industrial heritage as a tourism product [7].

Additionally, one can find initiatives that aim to strengthen industrial knowledge and production. As a reaction to the on-going financial crisis since 2008, policy makers are focusing more on a re-industrialisation of Europe fostering this development with strategy papers - such as the EU's policies for the industrial sector, laid out in the Competitiveness Report 2013 [1]. In connection to these aims the European Territorial Agenda 2020 demands a more focused approach towards endogenous, place-based (territorial) potentials [8]. Here the second, knowledge-based aspect of Industrial Culture comes into use: intangible assets, i.e. the existing skills, traditions and knowledge of oldindustrialised regions and its people. In the past old-industrialised regions were drivers of change, being entrepreneurial and innovative by developing specific mind-sets and skills in their field of production [9]. These intangible remains of the industrial age form a 
pivotal, but so far neglected resource in any re-industrialisation effort. A summary of the approach can be found in Figure 1.

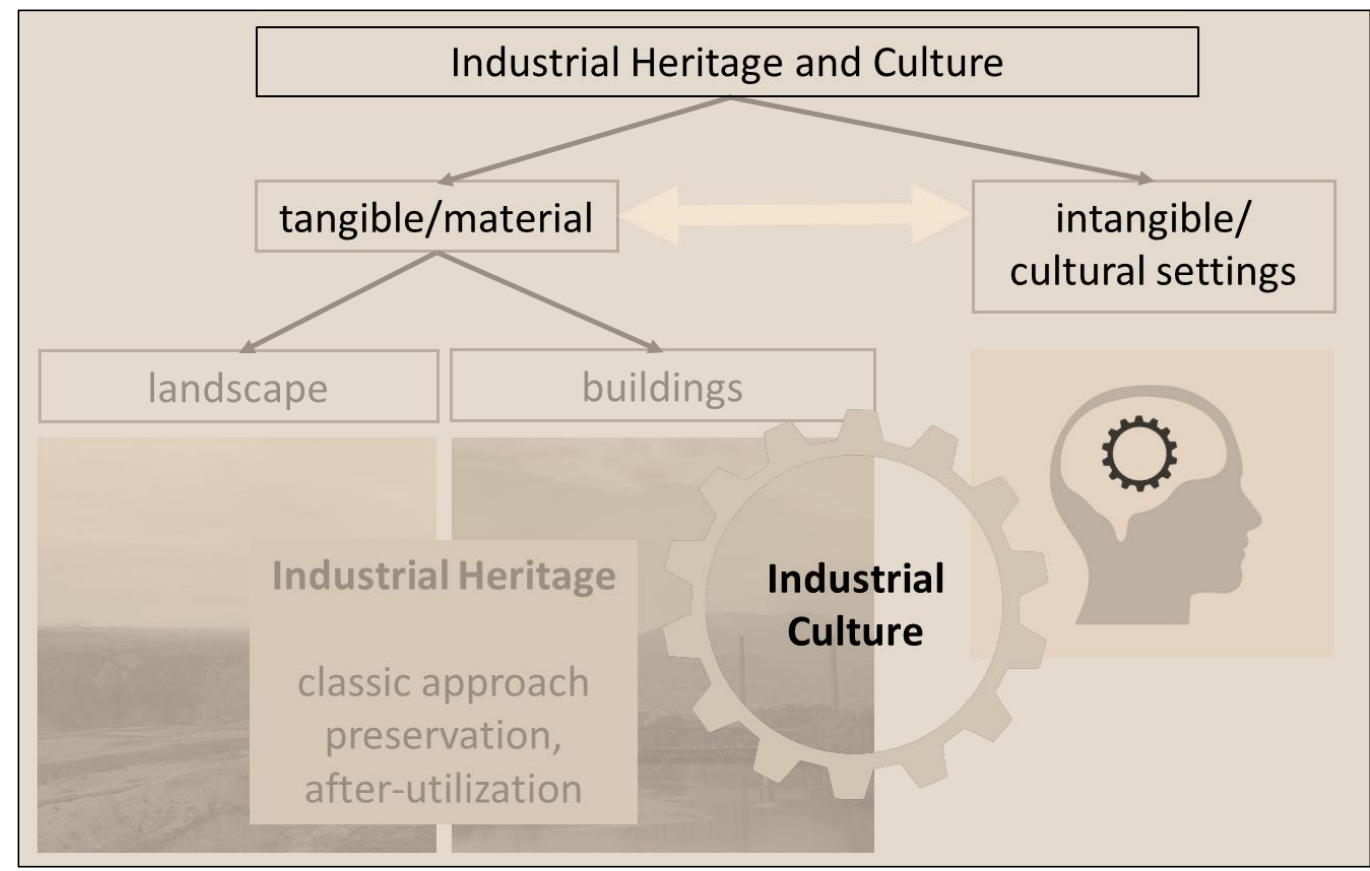

Figure 1. Post-industrial resources (own design)

Therefore, the main question in this context is how to utilise existing skills and knowledge of traditional industries with the demands of a globalised market economy, build on creativity and innovation - in other words how to activate the specific milieu of oldindustrialised regions and reactivate pioneer spirit to face nowadays challenges.

For Europe's old-industrialised regions that are situated outside agglomeration areas this question is especially difficult to answer. These regions often still possess highlycompetitive industrial units, albeit without the vast employment effect for the region, they once had [10]. Nevertheless, such places and industries face specific problems, which are often place-based. Being situated outside agglomeration areas results in a stronger reliance on local workforce and knowledge in order to remain competitive. This is a challenging task for regions with often high rates of outmigration, a lack of higher education facilities and the persistent negative image from the times of structural change [11].

Within this context described above, the INTERREG project "InduCult2.0" links regions with a distinct industrial past and present, which are situated outside major agglomeration areas in Central Europe. In recent years, all of them have undergone deep transformation processes due to automation, adaptation to globalized production patterns and the opening of markets in the former state-led economies. The long economic predominance of industrial production has brought about a particular cultural setting in the project partners' territories. It is made up of certain skills, attitudes, traditions as well as tangible monuments and artefacts. However, these regions are usually considered culturally less active and they are not utilizing the existing industrial culture to their full development potential [12]. 


\section{EXAMPLES}

To valorise the existing potentials in such areas project partners will embark on a range of activities dedicated to use Industrial Culture as a lever for regional development. Thereby they follow a combination of different elements of regional knowledge and sectors of society interlinking the industrial past, presence and future (Fig. 2). To illustrate the possible ways of utilisations the text will highlight some European examples which are already dealing-in one way or the other - with aspects of Industrial Culture.

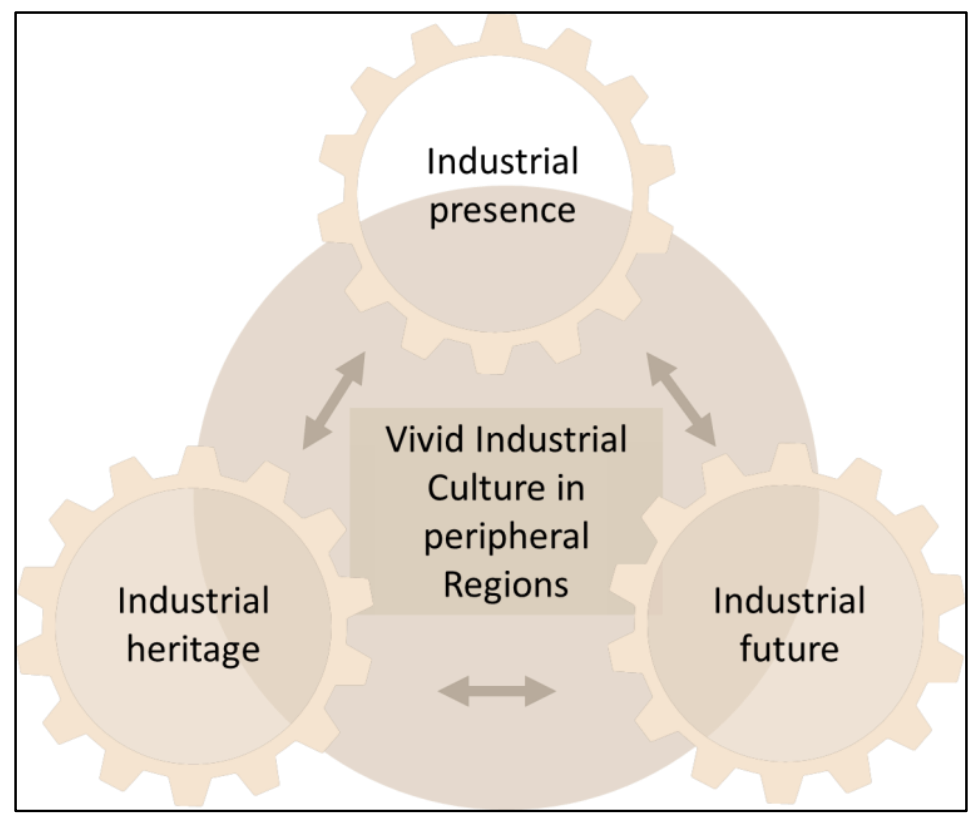

Figure 2. InduCult2.0 - Central idea (own design)

\section{Example 1:}

\section{Lange Nacht der Industrie - Long Night of Industry}

The long night of industry is an event format applied in various German towns and regions promoting industrial work places and companies. The concept follows similar formats (long night of science) by opening various companies for one night to visitors, providing guided tours and information on production techniques, work places and job opportunities. The concept is sometimes enlarged by cultural offers. More than 550 companies and 64.000 visitors were participating in 2016. It was implemented due to a lack of understanding of industry labour by locals and the role of industrial production for our society. The format usually includes a big kick-off-meeting in the regions and continues with information stands, guided tours, events, presentations, flyers, discussions, workshops in companies and production sites. The event also receives a high-level of media attention in the regions. The long night of industry creates a range of positive effects: By opening to the public the companies can change their often still negative image and promote the company to future employees. Visitors gain new awareness for regional industries and have a possibility to gain new knowledge about industrial production and its role for the regional development of these areas. www.langenachtderindustrie.de 


\section{Example 2:}

\section{Linz Tabakfabrik - Tobacco Factory Linz}

The Tabakfabrik (the Linz tobacco factory) is a $40.000 \mathrm{~m}^{2}$, old industrial space in the city of Linz (Austria). The initial building complex is a heritage-listed industrial site erected in the 1930s. The site contains Austria's very first steel frame building constructed in the New Objectivity style. The location witnessed industrial production in form of textile, and later tobacco processing for more than 300 years. The site is now being reconverted - in a step-by-step approach - into a major creative space. It is one of the many former industrial sites across Europe that has been re-modelled into a space for creative industries and consumerism.

The last tobacco production on site has ceased in the year 2009, when the city of Linz bought the property and started to convert the place with the aim to create the 'major creative hub in Upper Austria'. The case thereby represents -in contrast to other projects of such scale - a state-led revitalization initiative, securing long-term funding and political commitment. In this context the example is especially interesting, as it explicitly aims at the creation of value-chains between creative industries, research, arts and industries on the site. It represents a 'steered' approach towards the creation of innovation across various sectors. Next to the industrial innovation aspect, the site is currently also extensively used for art exhibitions and performances, following an artistic concept for the time of the refurbishment of the different buildings in the area.

For the concept of Industrial Culture, as discussed in this article, not only the setting in form of an old production site, but especially the direct link to new ways of production and product design is interesting. Thereby it creates a material manifestation between old and new forms of production incorporated in one place.

$\underline{\text { www.tabakfabrik-linz.at }}$

Example 3:

\section{Maker Faire}

Maker Faire is an event format first popularized in the United States, which received world-wide attention and follow-ups. It is in line with many other, also stationary innovation initiatives that circulate around the idea of 'making', i.e. FabLabs, Makerspaces, and Techshops etc. The core idea of all these formats is sharing knowledge and skills, as well as collaborating on innovation and creativity in various sectors.

The original Maker Faire format exists since 2006 and has gradually expanded to a worldwide event. The single events aim at bringing creative and innovative people ('maker') together in order to show-case their works, exchange knowledge and collaborate on design and development ideas. The events are usually open to the public, not limited to a certain sector and contain a cultural side program. Initial fairs where strongly marked by the participation of enthusiasts. Nowadays also research institutions, schools and companies are part of this maker scene meetings.

For the concept of Industrial Culture this approach is interesting, as also small and medium-sized towns with an industrial background started to adapt this format in order to foster innovation spirit.

www.makerfaire.com

\section{CONCLUSION}

The examples selected show different approaches of utilising Industrial Culture. They address different target groups - namely inhabitants, start-up companies and creative 
people in the cases discussed above. The aims of the initiatives are different: They range from raising interest and securing labour force for existing industries, building creative hubs for future industries and fostering innovative spirit by valorising the past, present and future aspect of industrial spaces and traditions, such as existing companies, buildings and innovative spirit. Different as the here portrayed approaches might be, they all use specific, place-bound potentials of (old) industrialised spaces. Moreover, the examples clearly address specific endogenous place-bound problems or needs of the municipalities or sectors in which they take place - thereby focussing directly on (perceived) needs of regional development in the regions.

This raises the question of how much potential such approaches have in terms of fostering regional development in old industrialised regions in Europe, especially when they are situated outside major agglomeration areas. Given the examples above, it is hard to assess the impact of these cases in connection to the postulated aims, especially as they often target soft factors. While financial viability or outreach of some of these approaches might be measureable, the real aims are long-term and difficult to assess by such formats, as other factors clearly play a role, when thinking of job choices, creativity and innovation. Nevertheless, these approaches allow regions to tap in already existing resources, because they address an important part of the history and presence of (old) industrial places. Thereby it reaches a higher level of acceptance and regional stakeholders can be motivated to sustain this development. It thereby creates an interesting platform for regional dialogue and action, which is otherwise often missing in such regions, where networks either are internally too strong ('lock-in') or externally too weak to generate new impulses for regional development. With the InduCult2.0 project the partner consortium hopes to create a deeper understanding on the possibilities and challenges when dealing with Industrial Culture in regional development.

\section{REFERENCES}

[1] European Commission. 2014. 'For a European Industrial Renaissance - SWD (2014), via www.eurlex.europa.eu/legalcontent/EN/TXT/PDF/?uri=CELEX:52014DC0014\&from=EN

[2] Pirke, K. 2010. 'Industriekultur Und Ihre Bedeutung Für GesellschaftlichPlanerische Prozesse Am Beispiel Der Erhebung von Industriekulturellen Potenzialen: Plädoyer Für Eine Angewandte Industriekulturforschung in Der Region'. Mitteilungsblatt des Instituts für Soziale Bewegungen 44: 171-186.

[3] Harfst, J., Fischer, W.. 2015. Innovative Heritage-Based Products: A Transnational Manual. 1st ed. Graz: University Graz. https://www.researchgate.net/publication/295400955_Innovative_Heritagebased_Products_-_A_transnational_manual

[4] Byrne, D. 2002. 'Industrial Culture in a Post-Industrial World: The Case of the North East of England'. City 6 (3): 279-289. doi:10.1080/1360481022000037733.

[5] European Parliament DG IP. 2013. 'INDUSTRIAL HERITAGE AND AGRI/RURAL TOURISM IN EUROPE IPOL-TRAN_ET'. Study report P/B/TRAN/FWC/2010-006/Lot5/C1/SC2. Brussels: European Parliament. ttp://www.europarl.europa.eu/RegData/etudes/etudes/join/2013/495840/IPOLTRAN_ET(2013)495840_EN.pdf. 
[6] Soyez, D. 2015. 'Europäische Industriekultur Als Touristisches

Destinationspotenzial'. Zeitschrift Für Wirtschaftsgeographie 50 (1): 75-84.

doi:10.1515/zfw.2006.0009.

[7] Hospers, G.-J.. 2002. 'Industrial Heritage Tourism and Regional Restructuring in the European Union'. European Planning Studies 10 (3): 397.

[8] EU Ministers of Spatial Planning and Territorial Development. „Territorial Agenda of the European Union 2020“, 2011. ww.eu2011.hu/files/bveu/documents/TA2020.pdf.

[9] Sadler, D., Thompson, J.. 2001. 'In Search of Regional Industrial Culture: The Role of Labour Organisations in Old Industrial Regions'. Antipode 33 (4): 660-686.

doi:10.1111/1467-8330.00205.

[10] Koutsky, J., Slach O., Boruta T. 2011. 'Restructuring Economies of Old Industrial Regions - Local Tradition, Global Trends'. In the Scale of Globalization. Think

Globally, Act Locally, Change Individually in the 21st Century, 166-173. Ostrava:

University of Ostrava.

[11] Wirth, P., Cernic-Mali, B., Fischer W., eds. 2012. Post-Mining Regions in Central Europe-Problems, Potentials, Possibilities. München: OEKOM. 